of the conducted webinars are defined: "What a Quiz is and How to Adapt It to the Educational Process»; "Vernissage of Pedagogical Ideas»; methodical workshop "Open-air Lesson of Thinking»; professional internship studios; pedagogical workshop «Innovative Mobility - 2021»; master class «Professional Development of a Teacher»;online conference «Distance Learning Technology as a Strategy for Updating Competency-Oriented Educational Environment» etc. The conclusion about the effectiveness of the use of mentioned forms of training is made. platform.

Key words: teacher training, natural sciences, technique, innovative activity, methodical

Дата надходженнястатті: 04.11.2021 p.

Рецензент: доктор педагогічних наук, доцент Примакова В. В.

\title{
МІЖДИСЦИПЛІНАРНА ОРГАНІЗАЦІЯ РОЗВИВАЯЬНОГО ОСВІТНЬОГО СЕРЕДОВИЩА В СИСТЕМІ ПІДГОТОВКИ МАЙБУТНІХ ФАРМАЦЕВТІВ
}

У статті розглянуто питання освітнвого та розвивального середовищза навчального закладу в процесі підготовки спеціалістів фармацевтичної галузі. Проаналізовано наукові та методичні джерела з питань забезпечення розвивального характеру освітнвого середовища вищої освіти у процесі використання міждисциилхінарного підходу до навчання. Розкрито основні позицї навчального процесу, що стосуються фармацевтичної сфери діяльності майбутніх випускників; підкреслено роль міждисциилінарного підходу до навчання із застосуванням навчально-дослідницького та інноваційного середовища в ході підготовки випускників спеціальності «Фармацція». Акцентовано увагу на реалізації ідеї міждисциилінарного підходу до навчання разом із сучасними концептуальними підходами до вдосконалення підготовки майбутніх фахівців фармацевтичної галузі, адже він стимулює вдосконалення процесу теоретичного чи практичного заняття; надае студентові розуміння взаємопов'язаності фахових дисичилін, потреби в удосконаленні знань та вмінь задля вирішення ситуаційних завдань у процесі традиційного практичного заняття, на практиці в аптечній установі.

На основі аналізу науково-педагогічних джерел з окресленої проблеми виокремлено ряд характеристик розвивального освітнвого середовища, які слір ураховувати у процесі взаємодіі усіх учасників освітнього процесу задля досягнення циілей навчального закладу та дотримання належних умов надання освітніх послуг, які повинні бути простором для повноцінного розвитку, осередком успішних, креативних і щзасливих людей.

Ці та інші аспекти дозволяють стверджувати про нагальність перегляду традиційних підходів щодо підготовки студентів навчальних закладів; виокремлення нових прийомів, методів, напрямів роботи з ними задля формування конкурентоздатного, висококвалібікованого, готового до змін працівника.

Ключові слова: освітне середовище, розвивальне середовище, інноваційне мислення, фармацевтична галузь, міждисцуиплінарний підхід, освітня діяльність, фактори впливу, дослідницька діяльність, самовдосконалення.

*(C) Аисенко Н. В.

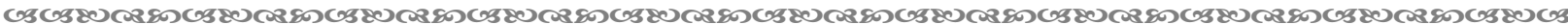
110 
Постановка проблеми. Система фармацевтичної освіти в Україні передбачає підготовку фахівців різних освітніх рівнів (молодшого бакалавра, бакалавра, магістра), а також фахівців для науково-педагогічної діяльності. Це зумовлюе організацію навчання здобувачів на базі повної (або неповної) середньої освіти у навчальних закладах I-IV рівнів акредитації до набуття майбутнім працівником відповідної професійної кваліфікації. Набута фармацевтична освіта дозволяе випускникам ЗВО займатися діяльністю, пов'язаною із виготовленням лікарських засобів в умовах аптек, належним їх зберіганням та відпуском (з аптек або їх структурних підрозділів).

Сьогодні підготовка таких фахівців здійснюеться Національним фармацевтичним університетом (Харків), фармацевтичними факультетами медичних університетів та академій, які функціонують у низці міст України (Вінниця, Дніпропетровськ, Донецьк, Запоріжжя, Івано-Франківськ, Луганськ, Аьвів, Київ, Одеса, Рубіжне, Тернопіль, Черкаси, Чернівці та Ужгород) за спеціальностями «Фармація», «Технологія фармацевтичних препаратів», «Клінічна фармація», «Технологія парфумернокосметичних засобів».

Для фармацевтичної освіти XXI ст. характерними є такі тенденції: досягнення стандартів європейського рівня; запровадження компетентнісного підходу на основі міждисциплінарного навчання; започаткування безперервного характеру вдосконалення фахової підготовки. Завдяки цьому уможливдюеться мобільність майбутнього фахівця та його конкурентоздатність на ринку праці.

Ці та інші тенденції знайшли відображення в основних принципах розвитку вищої освіти України у контексті Болонського процесу та підкріплені на законодавчому рівні, а саме в законах України «Про освіту», «Про вищу освіту» та Державній національній програмі «Освіта» («Україна XXI століття»).

Ідея впровадження міждисциплінарності (міжпредметності) у фахову підготовку була анонсована у Паризькому комюніке конференції ЮНЕСКО «Нова динаміка вищої освіти і науки для соціальної зміни і розвитку», де було наголошено на тому, що «освітні системи у вищій школі потрібно організувати більш гнучко, щоб просувати науку і міждисциплінарність (міжпредметність)» [2].

Тому сьогодні очевидно, що впровадження ідеї міждисциплінарності у процес підготовки майбутніх фахівців фармацевтичної галузі разом із сучасними концептуальними підходами до організаційно-змістового вдосконалення системи навчання є актуальним.

Аналіз досліджень. Вивченню проблеми забезпечення розвивального характеру освітнього середовища закладу вищої освіти присвячені роботи зарубіжних авторів (Є. Бондаревська, Дж. Гібсон, У. Мейс, М. Турвей, Дж. Равен, В. Сєріков, В. Ясвін та ін.) та вітчизняних дослідників (I. Бех, О. Керницький, С. Максимова, В. Рибалка, В. Семиченко, О. Ярошинська та ін.).

Однак, незважаючи на досить грунтовне та повне розкриття феномена «розвивальне середовище» та розроблення певних напрямів його формування у закладах вищої освіти, питання забезпечення розвивального характеру освітнього середовища у процесі використання міждисциплінарного підходу до навчання для майбутніх фармацевтичних працівників залишилось поза межами уваги науковців.

Мета статті - проаналізувати наукові та методичні джерела 3 питань забезпечення розвивального характеру освітнього середовища вищої освіти у процесі використання міждисципдінарного підходу до навчання; обгрунтувати важдивість застосування цього підходу у процесі підготовки випускників спеціальності «Фармація».

Викдад основного матеріалу. Основне завдання, яке держава ставить перед будьяким закладом вищої освіти, - це провадження освітньої діяльності на високому рівні, 
щоб забезпечити здобуття особами вищої освіти відповідного ступеня за обраними спеціальностями [7].

Слід зазначити, що навчання фахівців-фармацевтів в Україні, враховуючи міжнародні стандарти, грунтується на викдиках сучасності. Насамперед, маємо на увазі утвердження фармацевтичної галузі на основі якісної підготовки висококваліфікованих фахівців, усвідомлення громадськістю цінності професії, безперервного вдосконалення змісту освіти, використання ІКТ-технологій у здобутті освіти, застосування європейського досвіду, просування до євроінтеграційних процесів.

Дана сфера входить у систему охорони здоров'я, однак напрацьовує свою схему розвитку, зважаючи на якісну підготовку кадрів за всіма напрямами фармацевтичної діяльності. При цьому система навчання у вищих медичних (фармацевтичних) навчальних закладах переважно орієнтована на озброєння знаннями студента, формування фахових умінь і навичок шляхом подачі їх від викладача до студента, майбутнього випускника навчадьного закладу, але 3 урахуванням сучасних вимог до фахівців медичної та фармацевтичної промисловості вона стала малоефективною. Сьогодні відчувається потреба у якісних змінах навчання мододі. Тобто йдеться про нові педагогічні підходи з використанням елементів дистанційної форми навчання.

На сучасному етапі соціокультурногота інформаційно-цифрового розвитку суспільства, посилення інтегративних та інноваційних процесів у освіті й науці майбутні випускники спеціальності «Фармація» у процесі навчання мають засвоювати міжнаукові знання, опановувати професійно необхідні вміння і навички на міждисципдінарній основі. Це сприятиме не дише їхній продуктивній діяльності та конкурентоздатності на ринку праці, а й професійній мобільності.

Але не слід забувати і про умови надання освітніх послуг у закладах вищої освіти, які мають створювати основу для повноцінного професійного розвитку, а також бути осередками формування успішних, креативних і талановитих випускників. Тут має панувати атмосфера фізичного комфорту, сприятдивого соціального та психологічного клімату. Отже, маємо на увазі простір для навчання, розвитку та співпраці всіх учасників навчального процесу, де в кожного є мождивість відшукати себе.

Перш ніж зануритися у процес забезпечення розвивального характеру освітнього середовища навчального закладу у процесі міждисциплінарного підходу до навчання студентів-випускників спеціальності «Фармація», слід проаналізувати основні поняття «освітнє середовище», «розвивальне освітнє середовище».

Вітчизняні та зарубіжні науковці і практики висловдюють свої погдяди на освітнє середовище як частину самого життя людини, іï перебування у соціумі, що виявляється у сукупності всіх зовнішніх та внутрішніх чинників, які безпосередньо (чи опосередковано) впливають на особистість у процесі навчання та розвитку; це певний виховний простір, у якому відбувається іiі визначеність. Цікавим є підхід зарубіжного науковця В. Ясвіна, котрий переконаний, що освітне середовище це ті життеві ситуації, які відбуваються у самому закладі освіти, де сформовані індивідуальні методи впливів, використовуються просторові умови та предметні засоби, які забезпечують мождивість саморозвитку та самовдосконалення здобувача освіти [5, с. 16-17].

В. Сухомлинський писав, що середовище - «це і світ речей, що оточують учня, і вчинки старших, і особистий приклад вчителя, і загальний моральний тонус життя колективу (як матеріалізуеться ідея піклування про людину), чуйність, сердечність» [9, с. 190-191]. Видатний педагог звертає увагу на той факт, що «середовище не е чимось раз назавжди створеним і незмінним..., середовище має повсякденно створюватись і збагачуватись» [9, с. 191]. 
Такі ідеї визначних педагогів і науковців, не вагаючись, можна застосувати і до освітнього середовища закладу вищої освіти, адже в центрі уваги кожного з них дюдина, яка прагне до знань. I не важдиво, чи це буде учень, чи студент: ідеться про особистість зі своїм світоглядом, мисленням, прагненнями на певному етапі життя. На основі досліджень учених доходимо висновку, що освітнє середовище - це сукупність певних умов, відкритих можливостей із урахуванням матеріальних, фінансових, технологічних та організаційних можливостей для освіти особистості, що заплановані в закладі освіти, який виконує функції надання середньої чи вищої фахової освіти; надає мождивості для загальнокультурного та особистісного розвитку здобувачів освіти; впливає на професійно-особистісний розвиток майбутнього фармацевтичного фахівця, забезпечуючи його готовність до практичної діядьності чи продовження навчання, самореалізації [13].

Такий підхід дозволяе розгдядати будь-які 3 умов чи ресурсів освітнього середовища як «фактор впливу» на суб'єкта навчально-виховного процесу у закладі вищої освіти. Змінюючи їх, ми здатні впливати загалом на освітній процес, у тому числі на його резудьтат, - випускника навчального закладу. Освітне середовища вважається якісним, якщо воно здатне забезпечити всіх суб'єктів освітнього процесу мождивостями для задоволення освітніх потреб, саморозвитку та самовдосконалення. Постійне вивчення освітнього середовища шляхом аналізу, експериментів та удосконалення уже існуючих методів дає мождивість виявити нові шляхи для розвитку суб'єктів освітнього процесу, допомогти їх адаптуватись до умов освітнього середовища і сприяти максимальній реалізації освітніх цілей.

Однак для фармацевтичної сфери обслуговування необхідно враховувати ряд позицій.

По-перше, ми повинні вималювати взірець працівника. У кожного свої погляди на вирішення окресленого питання, тобто характеристику справжнього фахівця. I все це залежить від віросповідання, життєвого устрою, освіти та способу життя особи.

По-друге, у процесі навчання у закладі вищої освіти студент проходить складний шлях професійної орієнтації і формування, а на кінцевий вибір фаху впливають різні чинники, як особистісні, так і зовнішні, а саме затребуваність на ринку праці.

По-трете, загадьновідомо, що в однаковому середовищі, де діє єдина система впливів та умов, можуть у різних суб'єктів навчання відбуватися зміни різного типу (від позитивного розвитку особистості до регресу), оскільки вони по-різному взаємодіють із освітнім середовищем [4].

По-четверте, у закладі вищої освіти ми працюємо зі студентами, котрі вже мають сформовані погляди на життя.

Отже, виходячи з викладеного вище, а також на основі ідей філософської і науковопедагогічної літератури, зупинимося на визначенні освітнього середовища (запропонованого О. Керницьким) як педагогічного феномена: це континуум, що розвивається і «складається 3 просторово-тимчасових, соціально-культурних, діяльнісних, комунікативних, інформаційних та ін. факторів, які з'являються як цілеспрямовано створювані й спонтанні умови взаємодії особистості, що розвивається, і об'єктивного світу вищої школи. Взаємодія між ними проявляється у формі ситуацій та подій, що виникають у сферах ділових і міжособистісних контактів, творчих структур науково-педагогічних шкіл, предметно-просторового й інформаційного оточення; початком, який інтегрує та забезпечує індивідуальнопрофесійне становлення майбутніх фахівців» [1, с. 46].

Створення навчально-дослідницького середовища, починаючи 3 другого курсу фармацевтичного факультету, сприяе формуванню у здобувачів освіти позитивної 
мотивації, відповідального ставлення до навчання, стимулюе розвиток їхньої пізнавальної активності, почуття впевненості в собі та результатах власної діяльності.

На думку В. Сухомдинського, «педагоги працюють над вирішенням традиційних проблем: навчання - виховання, навчання - розвиток» [10, с. 69]. Але навчання, виховання і «розвиток немождиві, якщо ... одночасно не збуджується... інтерес до навчання $\mathrm{i}$... [бажання] вчитися, ... відчуття радості успіху, подолання труднощів» [10, с. 41], оскільки «праця душі повинна з'єднатися 3 працею думки і працею рук» [10, с. 70-71].

Ці слова ще раз підтверджують важдивість роботи викладача зі студентами, його професіоналізму, уміння контактувати, донести до них свою думку та допомогти знайти правильне рішення тих чи інших завдань, ситуаційних задач у процесі навчання з певної дисципліни. І звичайно ж, мотивація до навчання, самовдосконалення, яке породжує інтерес, є рушійною силою в отриманні результативності своєї праці.

У контексті зазначеного важдивого значення набуває розвиток інноваційного мислення особистості. На переконання В. Кременя, цього потребує «сама динаміка мінливого світу», яка залежить від культурного середовища, суспільного комфорту, інноваційної освіти [3, с. 233-234].

Інноваційне навчальне середовище - це «педагогічно доцільно організований простір життедіяльності, який сприяє розвитку інноваційного ресурсу особистості; інтегрований засіб накопичення і реалізації інноваційного потенціалу навчального закладу» [11]. Процес навчання особистості значною мірою має бути творчим. А також постає необхідність у формуванні прагнення досдідницької діяльності, тобто маємо на увазі «певну тривалу тенденцію до пошуків проблем у світі та самостійного їх подолання». Як слушно наголошуе Р. Швай, «інноваційна дюдина сприймає світ не як незмінну i гармонійну структуру, до якої легко можна пристосуватися, а як систему завдань, які потрібно вирішити» [12]; як «область пізнавальної і практичної непевності» [14, с. 39].

Це потребує упровадження інноваційних технологій у навчанні, вихованні та розвитку студентів вищих медичних (фармацевтичних) навчальних закладів; тісної співпраці закладів вищої освіти з практичною фармацією, оскільки самостійність кожної зі сторін не є результативною.

Міждисциплінарність не є винятком у такому процесі, а навпаки, сприяє реалізації усіх дидактичних принципів навчання, стимулює викладачів до оновлення змісту навчання, збагачення його цікавими та актуальними міждисциплінарними темами, новими соціальними ролями та комунікативними ситуаціями. При цьому відповідно до принципу інтеграції має бути взаємозв'язок всіх компонентів процесу навчання, елементів системи, що є основоположним у розробленні цілей навчання, визначенні його змісту, форм i методів. Реалізація міждисциплінарних зв'язків унавчальній діядьності - це один 3 необхідних дидактичних засобів формування у студентів професійних знань і навичок. Важливо, щоб навчальна інформація, засвоєна під час вивчення інших дисциплін, не повторювалась, а використовувалася для мотивації навчальної діяльності студентів, актуалізації опорних знань, умінь і навичок, обгрунтування, з' ясування сутності явищ, моделювання процесів тощо [5].

Міждисциплінарний підхід у цій ситуації стимулюе до вдосконалення процесу теоретичного чи практичного заняття, надає студентові розуміння взаємопов'язаності фахових дисциплін, потреби в удосконаленні знань та вмінь задля вирішення ситуаційних завдань у процесі традиційного практичного заняття, ділових ігор, на практиці в аптечній установі. I чим цікавіше студенту навчатися, тим 
продуктивнішим буде навчання. Адже подолання будь-яких труднощів додає упевненості у своїх силах, бажання долати нові вершини і відчувати радість перемог.

Міждисциплінарність веде до позитивних результатів: підвищення мотивації студентів до навчання; зростання якісних показників успішності навчання, підсумкової атестації; визначеність викладачів при підготовці до практичного чи теоретичного заняття. Але це не дозволяе нам з'ясувати якість готовності студентів до практичної діяльності в реальних умовах, оскільки кожна особистість розвивається за рахунок щоденної праці, пізнання нового, удосконалення тих знань, які вже нею набуті, оскільки освітне середовище не тільки всередині навчального закладу, воно і всередині фармацевтичної установи, де студенти проходять пропедевтичну чи переддипдомну практику. Тому питання проходження практики студентів на фармацевтичних підприємствах чи в аптечних установах нашої країни відкрите і потребує вирішення не тільки на рівні навчальних закладів, а й на рівні держави. На жаль, більшість приватних фармацевтичних установ відмовляеться брати студентів для проходження практики. Вирішення цього питання повинно бути чітко прописане в документах, що стосуються господарської діяльності з виробництва дікарських засобів, оптової та роздрібної торгівді ними, а також виробами медичного призначення. Коди ти ставиш певні умови іншій стороні у своїй діядьності, будь готовим прийняти у відповідь такі ж умови і до себе. Якщо ти хочеш мати висококласного спеціаліста фармацевтичної справи надай йому можливість удосконалити свої знання та практичні навички, отримані у стінах навчального закдаду, відчути себе корисним як для підприємства, так і суспільства, відчути впевненість у собі, готовність до праці, подадьшого розвитку у цьому напрямі.

Як засвідчують результати нашого дослідження, у сучасній педагогічній практиці існуе чимало труднощів щодо створення розвивального освітнвого середовищца, зорієнтованого на розвиток фахової талановитості. Освітне середовище як складова багаторівневої системи не має визначального впливу на фаховий і соціальний розвиток особистості, позаяк, 3 одного боку, є родина, мікрокдімат освітнього закдаду, навколишне середовище, а з іншого - економічні, політичні, соціальні, культурні, ідеологічні, релігійні та інші суспільні чинники. Тому розвивальне освітнє середовище дише уможливлює (але не гарантує) формування творчо розвиненої особистості, яка усвідомлює, що власні досягнення є результатом власної пізнавальної діяльності.

Аналіз науково-педагогічних джерел 3 питань, пов'язаних з розвивальним освітнім середовищем, дозволив виокремити (услід, за В. Мелешко [4] й А. Смолюк [8]) його фахово значущі особливості: «домінантність - це наявність у середовищі потенціалу для розвитку особистісних цінностей» [там само, с. 42] студента, його значущість щодо впливу на зростаючу особистість інших соціальних чинників; позитивне середовище в навчальному закладі мало домінантне значення у становленні студента; «педагогічна інтенсивність - динамічна характеристика, що засвідчуе ступінь насиченості відповідного середовища шияхом використання викладачем педагогічних інновацій, нетрадиційних форм i методів організації навчально-виховного процесу ...[в навчальному закладі] (тренінги, ділові ігри, проєктні та комп'ютерні технології тощо)» [там само, с. 42] з обов'язковим використанням міждисциплінарної інтеграціі); «широта - пов'язана зі структурно-змістовною характеристикою, що засвідчуе міру включення ...[здобувача освіти (першокурсника)] в конкретне середовище (наприклад, освітне середовище випускника сільської школи, вихідця із малозабезпеченої чи неповної сім'ї значно вирізняється від оточення його ровесника, що проживає в місті і має значно ширші можливості для розвитку здібностей у позашкільних навчальних закладах, інформаційних центрах, пізнання довкілдя та збагачення особистісного 
досвіду у міжнародних подорожах, зустрічах з авторитетними постатями тощо)» [там само, с. 42-43]; «емоційна насиченість - ефективне співвідношення в середовищі емоційного й раціонального компонентів, тобто спрямованість на його збагачення в емоційному плані» [там само, с. 43]; «соціокультурна мобільність - слугує критерієм соціально орієнтованого творчого потенціалу середовища, його здатність до прогресивних змін, оперативного впровадження інновацій з урахуванням суспільних вимог (передусім регіональних), взаємодії з ... навчальними закладами, громадськими організаціями тощо» [там само, с. 43]; «координованість - узгодження цілей, змісту, форм та методів діядьності всіма учасниками педагогічного процесу ... [освітнього] закладу, налагодження активної співпраці між ними заради створення ефективного розвивального освітнього середовища» [там само, с. 43] закладу вищої освіти; «стійкість - засвідчуе стабільність середовища щодо цілеспрямованого прогресивного впливу на розвиток і саморозвиток кожного [там само, с. 43] здобувача освіти, реалізації його творчого потенціалу в освітньому процесі; продукування та збереження педагогічних традицій у системі підготовки фахівців.

Висновки. Таким чином, розвивальний характер освітнього середовища навчального закладу у процесі використання міждисциплінарного підходу до навчання - це непростий процес розвитку і становлення особистості, що слугуе чинником формування поведінки. Відповідно на формування поведінки впдиває середовище, взаємодія особистості з його складовими.

Ці та інші аспекти дозволяють стверджувати про нагальність перегдяду традиційних підходів щодо підготовки студентів навчальних закладів; виокремлення нових прийомів, методів, напрямів роботи 3 ними задля формування конкурентоздатного, висококваліфікованого, готового до змін працівника.

\section{Список використаних джерел:}

1. Керницький О.М. Освітне середовище вищого навчального закдаду як педагогічний феномен. Проблеми інженерно-педагогічної освіти, 2013. № 38-39. С. 43-50. URL: http://nbuv.gov.ua/UJRN/Pipo $2013 \quad 38-398$

2. Комюніке Всесвітньої конференції з вищої освіти - 2009: «Нова динаміка вищої освіти і науки для соціальної зміни і розвитку» ЮНЕСКО, Париж, 5-8 липня 2009 року (8 липня 2009 р.). URL: https://zakon.rada.gov.ua/laws/show/952 011\#Text

3. Кремень В.Г. Філософія людиноцентризму в освітньому просторі. 2-ге вид. Київ: Знання, 2011. $349 \mathrm{c}$.

4. Мелешко В. Особливості формування навчально-виховного середовища у сільській школі. URL: visnuk 10.pdf

5. Микитюк О. Ю. Міжпредметна інтеграція при вивченні медичної і біологічної фізики як фактор формування наукового світогляду майбутнього лікаря. Кредитно-модульна система організації навчального процесу у вищих медичних (фармацевтичному) навчальних закладах України на новому етапі: матеріали доп. Х ювіл. Всеукр. навч.-наук. конф. з міжнар. участю (18-19 квіт. 2013 р.). Тернопіль: ТДМУ, 2013. Ч. 2. С. 602-604.

6. Музика А. О., Корольов Д. К., Семенова Р. О. та ін. Психологічні засади розвитку обдарованої особистості в освітньому середовищі: методичний посібник [за ред. О. А. Музики]. Київ-Житомир: Вид-во ЖДУ ім. І. Франка, 2015. 146 с.

7. Про вищу освіту: Закон України від 01.07.2014 p. № 1556-VIIURL: https://zakon.rada.gov.ua/laws/show/1556-18\#Text

8. Смолюк С. В. Організаційно-педагогічні умови становлення розвивального освітнього середовища в системі початкової освіти України (кінець XX - початок XXI ст.): дис. ... канд. пед. наук: 13.00.01. Ауцьк, 2017. 277 с. 
9. Сухомлинский В. А. Разговор с мододым директором школы. 2-е изд. Москва: Просвещение, 1982. $206 \mathrm{c}$.

10. Сухомдинский В. А. О воспитании. Москва: Подитиздат, 1973. 270 с.

11. Шапран Ю. П., Шапран О.І. Створення інноваційного освітнього середовища в процесі підготовки майбутнього вчителя. URL: http://www.sportpedagogy.org.ua/html/journal/201009/10soitpt.pdf

12. Швай P. I. (2010). Формування інноваційної особистості. Гуманізм та освіта: електронне наукове видання матеріалів конференціï, 2010. URL: http://conf.vntu.edu.ua/humed/2010/txt/ Shvay.php

13. Ярошинська О. Середовищний підхід в професійній освіті: теоретичні засади та перспективи впровадження. Проблеми підготовки сучасного вчителя, 2011. № 4 (1). С. 104-109. URL: http://nbuv.gov.ua/UJRN/ppsv 2011 4\%281\%29 19

14. KozieleckiJ. Człowiek wielowymiarowy. Warszawa: Zak, 1996. $290 \mathrm{s.}$

\section{References:}

1. Kernytskyi, O. M. (2013). Osvitnie seredovyshche vyshchoho navchalnoho zakladu yak pedahohichnyi fenomen [Educational environment of a higher education institution as a pedagogical phenomenon]. Problemy inzhenerno-pedahohichnoi osvity, 38-39, 43-50. Retrieved from http://nbuv.gov.ua/UJRN/Pipo_2013 38-39_8 [in Ukrainian].

2. Communiqué of the World Conference on Higher Education, 2009: "New Dynamics of Higher Education and Science for Social Change and Development" by UNESCO, Paris, dated July 5-8, 2009 (July 8, 2009). Retrieved from https://zakon.rada.gov.ua/laws/show/952_011\#Text [in Ukrainian].

3. Kremen, V.H. (2011). Filosofiia liudynotsentryzmu $v$ osvitnomu prostori [Philosophy of anthropocentrism in the educational space]. Kyiv: Znannia [in Ukrainian].

4. Meleshko, V. Osoblyvosti formuvannia navchalno-vykhovnoho seredovyshcha u silskii shkoli [Peculiarities of formation of educational environment in rural school]. Retrieved from https://library.udpu.edu.ua/library files/psuh pedagog probl silsk shkolu/15/visnuk 10.pdf [in Ukrainian].

5. Mykytiuk, O. Yu., Boiechko, V. F., \& Olar, O. I. (2013). Mizhpredmetna intehratsiia pry vyvchenni medychnoi i biolohichnoi fizyky yak faktor formuvannia naukovoho svitohliadu maibutnoho likaria [Interdisciplinary integration in the study of Medical and Biological Physics as a factor in forming the scientific worldview of the future doctor], Kredytno-modulna systema orhanizatsii navchalnoho protsesu $u$ vyshchykh medychnykh (farmatsevtychnomu) navchalnykh zakladakh Ukrainy na novomu etapi, materialy dop. XX yuvileinoi Vseukrainskoi navchalno-naukovoi konferentsiia $\mathrm{z}$ mizhnarodnoiu uchastiu [Credit-modular system of organization of educational process in higher medical (pharmaceutical) educational institutions of Ukraine at the new stage, Proceedings of the Xth Anniversary All-Ukrainian Educational and Scientific Conference with International Participation]. Ternopil: TDMU [in Ukrainian].

6. Muzyka, L. O., Korolev, D. K., \& Semenova, R. O. (Ed.). (2015). Psykholohichni zasady rozvytku obdarovanoi osobystosti $v$ osvitnomu seredovyshchi [Psychological principles of gifted personality development in the educational environment]. Kyiv-Zhytomyr: Vyd-vo ZhDU im. I. Franka [in Ukrainian].

7. On Higher Education, Law of Ukraine dated July 1, 2014 No. 1556-VII. Retrieved from https://zakon.rada.gov.ua/laws/show/1556-18\#Text [in Ukrainian].

8. Smoliuk, S. V. (2017). Orhanizatsiino-pedahohichni umovy stanovlennia rozvyvalnoho osvitnoho seredovyshcha $v$ system $i$ pochatkovoi osvity Ukrainy (kinets XX - pochatok XXI st.) [Organizational and pedagogical conditions for the formation of a developmental educational environment in the system of primary education in Ukraine (late XX - early XXI century)]. (Candidate's thesis). Lutsk [in Ukrainian].

9. Sukhomlinsky, V. A. (1982). Razgovor s molodym direktorom shkoly [Conversation with the young headmaster of the school]. Moskva: Prosveshchenie [in Russian].

10. Sukhomlinsky, V. A. (1973). O vospitanii [On upbringing]. Moskva: Politizdat [in Russian]. 
11. Shapran, Yu. P, \& Shapran, O. I. (2010). Stvorennia innovatsiinoho osvitnoho seredovyshcha v protsesi pidhotovky maibutnoho vchytelia [Creating an innovative educational environment in the process of preparing a future teacher]. Retrieved from http://www.sportpedagogy.org.ua/html/journal/ 2010-09/10soitpt.pdf [in Ukrainian].

12. Shvai, R. I. (2010). Formuvannia innovatsiinoi osobystosti. Humanizm ta osvita: elektronne naukove vydannia materialiv konferentsii [Formation of innovative personality. Humanism and education: electronic scientific publication of conference materials]. Retrieved from http://conf.vntu.edu.ua/ humed/2010/txt/Shvay.php [in Ukrainian].

13. Yaroshynska, O. (2011). Seredovyshchnyi pidkhid v profesiinii osviti: teoretychni zasady ta perspektyvy vprovadzhennia. Problemy pidhotovky suchasnohovchytelia [Environmental approach in vocational education: theoretical principles and prospects of implementation. Problems of modern teacher training], 4 (1), 104-109. Retrieved from http://nbuv.gov.ua/UJRN/ppsv $20114 \% 281 \% 29 \quad 19$ [in Ukrainian].

14. Kozielecki, J. (1996). Liudyna bahatovymirna [Człowiek wielowymiarowyielecki]. Warszawa: Zak. [in Polish].

Lysenko N. V., orcid.org/0000-0002-6526-6104

\section{INTERDISCIPLINARY ORGANIZATION OF THE DEVELOPMENTAL EDUCATIONAL ENVIRONMENT IN THE SYSTEM OF FUTURE PHARMACISTS' PREPARATION}

The article considers the issues of educational and developmental environment of the educational institution in the process of training specialists in the pharmaceutical industry. Scientific and methodological sources on ensuring the developmental nature of the educational environment of higher education in the process of using an interdisciplinary approach to learning are analyzed.The main positions of the educational process concerning the pharmaceutical sphere of activity of future graduates are revealed; the role of interdisciplinary approach to learning with the use of educational, research and innovation environment in the preparation of graduates of the specialty "Pharmacy" is emphasized. Emphasis is placed on the implementation of the idea of interdisciplinary approach tolearning together with modern conceptual approaches to improving the training of future professionals in the pharmaceutical industry, because it: stimulates to improve the process of theoretical or practical training; provides the student with an understanding of the interconnectedness of professional disciplines, the need to improve knowledge and skills to solve situational problems in the process of traditional practical training, in practice in a pharmacy.

Based on the analysis of scientific and pedagogical sources on the outlined problem, a number of characteristics of the developmental educational environment are identified, which should be taken into account in the interaction of all participants in the educational process to achieve the goals of the educational institution, creative and happy people.

These and other aspects suggest the urgency of reviewing traditional approaches to training students; identification of new techniques, methods, areas of work with them in order to form a competitive, highly qualified, ready for change employee.

Key words: educational environment, development environment, innovative thinking, pharmaceutical industry, interdisciplinary approach, educational activity, factors of influence, research activity, self-improvement. 